\title{
Detection of livestock-associated meticillin-resistant Staphylococcus aureus CC398 in retail pork, United Kingdom, February 2015
}

N F Hadjirin'1, E M Lay¹, G K Paterson², E M Harrison³, S J Peacock ${ }^{3,4}$, J Parkhill4, R N Zadoks 5,6, M A Holmes (mah1@cam.ac.uk)

1. Department of Veterinary Medicine, University of Cambridge, Cambridge, United Kingdom

2. School of Biological, Biomedical and Environmental Sciences, University of Hull, Hull, United Kingdom

3. Department of Medicine, University of Cambridge, Cambridge, United Kingdom

4. The Wellcome Trust Sanger Institute, Wellcome Trust, Cambridge, United Kingdom

5. Moredun Research Institute, Penicuik, United Kingdom

6. University of Glasgow, Institute of Biodiversity, Animal Health and Comparative Medicine, Glasgow, United Kingdom

Citation style for this article:

Hadjirin NF, Lay EM, Paterson GK, Harrison EM, Peacock SJ, Parkhill J, Zadoks RN, Holmes MA. Detection of livestock-associated meticillin-resistant Staphylococcus aureus CC398 in retail pork, United Kingdom, February 2015. Euro Surveill. 2015;20(24):pii=21156. Available online: http://www.eurosurveillance.org/ViewArticle. aspx?Articleld $=21156$

Livestock-associated meticillin-resistant Staphylococcus aureus belonging to clonal complex 398 (LA-MRSA $\mathrm{CC}_{398}$ is an important cause of zoonotic infections in many countries. Here, we describe the isolation of LA-MRSA CC398 from retail meat samples of United Kingdom (UK) farm origin. Our findings indicate that this lineage is probably established in UK pig farms and demonstrate a potential pathway for the transmission of LA-MRSA CC 398 from livestock to humans in the UK.

A survey was conducted in February 2015 to detect meticillin-resistant Staphylococcus aureus (MRSA) in retail meat products obtained from supermarkets in the United Kingdom (UK). A total of 103 (52 pork and 51 chicken) pre-packaged fresh meat products, labelled as being of UK farm origin, were purchased from supermarkets in five different locations (Locations A-E) in the UK. All meat products were frozen $\left(-20^{\circ} \mathrm{C}\right)$ and sent to the Department of Veterinary Medicine, University of Cambridge, for testing.

\section{Preparation and testing of meat samples}

The preparation of meat samples followed the European standard ISO 6887-2:2003 [1]. After thawing, the exterior packaging was disinfected before the meat was removed. A $10 \mathrm{~g}$ sample of meat was excised, mixed with $225 \mathrm{ml}$ of $6 \% \mathrm{w} / \mathrm{v} \mathrm{NaCl}$ Nutrient Broth ( $\mathrm{P}$ and $\mathrm{O}$ laboratories, UK) and homogenised using a Stomacher (Stomcher8o Laboratory System, Seward Ltd, UK) for two minutes. Enrichment for $S$. aureus was performed as previously described [2]. Identification of potential MRSA colonies (blue colour) was confirmed by subculture on MRSA Brilliance 24 plates (Oxoid, Baskingstoke, UK) which were subsequently screened for $\mathrm{mec} A$, mecC and femB by multiplex PCR as described previously [3].
Potential MRSA colonies subjected to PCR testing initially yielded two mecA positive cultures (samples $C_{7}$ and D8). Three colonies from subcultures from each of these original samples were spa typed as described previously [4] which yielded a single spa type from one sample and two different spa types from the other.

\section{Antimicrobial susceptibility testing}

The antimicrobial susceptibility of all three isolates was analysed using the VITEK 2 system (bioMérieux, Basingstoke, UK) in accordance with the manufacturer's instructions using a Staph AST-P635 card with results interpreted using European Committee on Antimicrobial Susceptibility Testing (EUCAST) breakpoints [5]. Antimicrobial susceptibility results (Table 1) showed that all three isolates were phenotypically MRSA and were additionally resistant to tetracycline and trimethoprim.

\section{Genomic analyses}

Genomic DNA of all three S. aureus isolates was extracted from overnight cultures grown in TSB at $37^{\circ} \mathrm{C}$ using the MasterPure Gram Positive DNA Purification Kit (Cambio, Cambridge, UK). Illumina library preparation was carried out as described by Quail et al. [6] and Mi-Seq sequencing was carried out following the manufacturer's standard protocols (Illumina, Inc., San Diego, (A, US). Genomes were assembled de novo from Fastq files with Velvet [7]. The draft sequences for $\mathrm{C}_{7-1}, \mathrm{C}_{7}-2$ and D8 had a total of 38,22 and 31 contigs, respectively. Comparative genomics were carried out using WebACT and viewed with the Artemis comparison tool (ACT) [8]. The presence of antibiotic resistance genes was identified using the ResFinder-1.3 Server [9] and by BLAST [10] against the assemblies. Nucleotide sequences of isolates $C_{7-1}, C_{7-2}$ and $D 8$ have been 
Antimicrobial susceptibility characteristics of meticillin-resistant Staphylococcus aureus CC398 from retail pork samples, United Kingdom, February $2015(\mathrm{n}=3)$

\begin{tabular}{|l|c|c|c|c|c|c|c|c|}
\hline Isolate & Benzylpenicillin & Cefoxitin & Oxacillin & Ciprofloxacin & Clindamycin & Erythromycin & Tetracycline & Trimethoprim \\
\hline C7-1 & $\mathrm{R}$ & $\mathrm{R}$ & $\mathrm{R}$ & $\mathrm{R}$ & $\mathrm{S}$ & $\mathrm{S}$ & $\mathrm{R}$ & $\mathrm{R}$ \\
\hline C7-2 & $\mathrm{R}$ & $\mathrm{R}$ & $\mathrm{R}$ & $\mathrm{S}$ & $\mathrm{R}$ & $\mathrm{S}$ & $\mathrm{R}$ & $\mathrm{R}$ \\
\hline D8 & $\mathrm{R}$ & $\mathrm{R}$ & $\mathrm{R}$ & $\mathrm{R}$ & $\mathrm{S}$ & $\mathrm{R}$ & $\mathrm{R}$ & $\mathrm{R}$ \\
\hline
\end{tabular}

R: resistant; S: susceptible.

Results of testing using a VITEK 2 system (bioMérieux, Basingstoke, UK) using a Staph AST-P635 card (testing for susceptibility to cefoxitin, benzylpenicillin, oxacillin, gentamycin, ciprofloxacin, clindamycin, erythromycin, linezolid, daptomycin, teicoplanin, vancomycin, tetracycline, fusidic acid, mupirocin, chloramphenicol, rifampicin, and trimethoprim). All three isolates were susceptible to gentamycin, linezolid,

daptomycin, teicoplanin, vancomycin, fusidic acid, mupirocin, chloramphenicol and rifampicin. Breakpoints were interpreted according to the European Committee on Antimicrobial Susceptibility Testing (EUCAST) guidelines.

deposited in the European short read archive with accession numbers ERR902083, ERR902084 and ERR902085, respectively.

Multilocus sequence typing using the assembly sequences found that all three isolates belonged to sequence type ST398 and carried a composite staphylococcal cassette chromosome mec (SCCmec) $\mathrm{V}\left({ }_{5} \mathrm{C}_{2}\right.$ and 5)c element including the cadmium and zinc resistance gene $\operatorname{czrC}$ [11]. All isolates lacked the lukS-PV and lukF-PV genes encoding Panton-Valentine leukocidin and the human-associated immune evasion cluster genes sak, scn and chp (often carried by the phage $\varphi$ Sa3) [12]. All three isolates carried an extra copy of the von Willebrand factor-binding protein ( $\mathrm{vWbp}$ ) gene, $v w b$ previously found on pathogenicity island SaPIbov 5 in a ST398 isolate which confers the ability to clot ruminant plasma [13]. Genomic analysis demonstrated the presence of the tetracycline resistance genes tet(M) and tet $(\mathrm{K})$ in addition to $m e c A$, in all three isolates, together with other resistance determinants which varied between isolates and matched their antimicrobial susceptibilities (Tables 1 and 2). Three canonical single nt polymorphisms (canSNP) shown by Stegger et al. [14] to distinguish between human and livestock clades of ST398 had the livestock associated nt in all three positions for all three of the isolates.

\section{Discussion}

Here we describe the first isolation of LA-MRSA ST398 from retail meat originating from farms in the UK. Recent reports of $\mathrm{CC}_{398} 8$ isolates from horses [15], dairy cattle [2], poultry [16], and pigs [17,18] indicate that this lineage is widely distributed in the UK. In many countries LA-MRSA CC398 represents an occupational risk for those in close contact with livestock,

\section{TABLE 2}

Molecular characteristics of meticillin-resistant Staphylococcus aureus CC398 from retail pork samples, United Kingdom, February $2015(\mathrm{n}=3)$

\begin{tabular}{|c|c|c|c|c|c|c|c|c|c|c|c|c|}
\hline Isolate & Location & $\begin{array}{l}\text { Meat } \\
\text { type }\end{array}$ & MLST & spa Type & $\begin{array}{c}\mathrm{SCCmec} \\
\text { type }\end{array}$ & $\varphi \mathrm{Saz}_{3}$ & $\begin{array}{c}\text { canSNP } \\
748\end{array}$ & $\begin{array}{c}\text { canSNP } \\
1002\end{array}$ & $\begin{array}{c}\text { canSNP } \\
3737\end{array}$ & $\operatorname{tet}(\mathrm{M})$ & $\operatorname{tet}(\mathrm{K})$ & Other \\
\hline $\mathrm{C}_{7-1}$ & C & $\begin{array}{c}\text { Pork } \\
\text { sausage }\end{array}$ & $\mathrm{ST} 398$ & to11 & $\begin{array}{l}\mathrm{V}(5 \mathrm{C} 2 \\
\text { and } 5) \mathrm{c}\end{array}$ & Neg & LA & LA & LA & Pos & Pos & $\begin{array}{l}\text { blaz } \\
\text { dfrk }\end{array}$ \\
\hline $\mathrm{C}_{7-2}$ & C & $\begin{array}{c}\text { Pork } \\
\text { sausage }\end{array}$ & $\mathrm{ST} 398$ & to34 & $\begin{array}{c}V(5 \mathrm{c} 2 \\
\text { and } 5) \mathrm{c}\end{array}$ & Neg & LA & LA & LA & Pos & Pos & $\begin{array}{l}\text { blaz } \\
\text { dfrG } \\
\text { spc } \\
\text { linB } \\
\text { aadg }\end{array}$ \\
\hline D8 & D & $\begin{array}{l}\text { Pork } \\
\text { mince }\end{array}$ & $\mathrm{ST} 398$ & to34 & $\begin{array}{c}\mathrm{V}(5 \mathrm{c} 2 \\
\text { and } 5) \mathrm{c}\end{array}$ & Neg & LA & LA & LA & Pos & Pos & $\begin{array}{c}\text { blaZ } \\
\text { dfrG } \\
\text { aadD } \\
\ln u(B) \\
\operatorname{erm}(C) \\
\operatorname{lin} B \\
\text { cadR } \\
\text { merR }\end{array}$ \\
\hline
\end{tabular}

LA: livestock-associated; MLST: Multilocus sequence typing; Neg: negative; Pos: positive.

The $\varphi$ Saz phage is associated with human ST398 isolates which carries a cluster of human immune evasion genes [14]. The columns headed canSNP748, canSNP1002 and canSNP3737 refer to canonical SNPs described by Stegger et al. [14] associated with human- or livestockassociated lineages. The antimicrobial resistance genes were identified using the ResFinder-1.3 Server [9]. 
particularly pigs and veal calves. For example, significantly higher rates of CC398 MRSA nasal carriage by humans in contact with pigs (farm workers, abattoir workers, veterinarians) have been shown in epidemiological studies [19-22]. Other studies have revealed an association between clinical disease resulting from LA-MRSA CC398 infection and recent contact with pigs or pig farms [23-27]. As with other MRSA, LA-MRSA CC398 may be responsible for serious illness following wound or surgery site infections. They may also contribute to increased healthcare costs due to screening, isolation of carriers, and decolonisation. Adequate cooking (heating above $71^{\circ} \mathrm{C}$ ) and hygienic precautions during food preparation should minimise the likelihood of human colonisation via contaminated pork. Still our finding of LA-MRSA CC398 in pork identifies a potential pathway from farms to the wider population. Cuny et al. [28] identified thawing liquid of broiler chicken carcasses as having greater numbers of bacteria which may represent an increased risk for frozen meats. Our study did not examine the thaw water separately and also failed to find ST398 in poultry samples which suggests that this lineage may be present in the UK at lower rates than in continental Europe; however, further studies are required to establish this.

While human contamination of carcasses or meat products in the abattoir or at the meat packing plant may occur, there is evidence that the ST398 isolates are of animal origin. The isolates carried tetracycline resistance genes, lacked the human virulence phage, $\varphi$ Sa3, possessed the three canonical SNPs previously shown to identify animal lineages and copies of the von Willebrand factor-binding protein ( $\mathrm{vWbp}$ ) gene associated with livestock $[13,14]$. The ST398 isolates all came from processed pork (sausages and minced pork) likely to comprise meat from multiple carcases. Testing of these meat products used a highly sensitive method of detection of bacterial contamination and so the numbers of MRSA present may be low. It cannot be ruled out that the meat packing plants from which the MRSA from this study originated also handle imported meat. If this were the case, it is conceivable that cross-contamination might have occurred between non-UK to UK sourced meat. Further phylogenetic studies are required to provide evidence to examine that possibility.

\section{Conclusions}

This is the first description of LA-MRSA CC398 in retail meat products in the UK. The presence of a lineage capable of colonising a wide range of host species with a zoonotic potential make this finding of significance for both human and animal health. Furthermore, the presence of LA-MRSA CC398 in the human food chain demonstrates in addition to the established risk through direct contact with animals a possible further pathway for the transmission of antimicrobial resistance from livestock to the broader human population, and not just via those with direct contact with farm animals.
Acknowledgments

This work was supported by a Medical Research Council Partnership Grant ( $\mathrm{G}_{1001787 / 1)}$ held between the Department of Veterinary Medicine, University of Cambridge (M.A.H), the School of Clinical Medicine, University of Cambridge (S.J.P), the Moredun Research Institute (R.N.Z), and the Wellcome Trust Sanger Institute (J.P and S.J.P). Sample collection and financial support was also provided by the Alliance to Save our Antibiotics.

\section{Conflict of interest}

None declared.

Authors' contributions

Nazreen $\mathrm{F}$ Hadjirin performed laboratory work and wrote the manuscript, Elizabeth $M$ Lay collected samples and performed laboratory work, Gavin K Paterson performed some of the laboratory work and contributed to the manuscript, Ewan M Harrison performed some of the analysis and contributed to the manuscript, Sharon J Peacock edited the manuscript, Julian Parkhill edited the manuscript, Ruth $\mathrm{N}$ Zadoks edited the manuscript, Mark A Holmes designed the study, supervised the laboratory work, undertook some of the analysis and edited the manuscript.

\section{References}

1. International Organization for Standardization (ISO). ISO 6887-2:2003-Microbiology of Food and Animal Feeding Stuffs - Preparation of Test Samples, Initial Suspension and Decimal Dilutions for Microbiological Examination - Part 2: Specific Rules for the Preparation of Meat and Meat Products. Geneva: ISO. 2003.

2. Paterson GK, Larsen J, Harrison EM, Larsen AR, Morgan FJ, Peacock SJ, et al. First detection of livestock-associated meticillin-resistant Staphylococcus aureus CC398 in bulk tank milk in the United Kingdom, January to July 2012. Euro Surveill. 2012;17(50). PMID:23241232

3. Paterson GK, Larsen AR, Robb A, Edwards GE, Pennycott TW, Foster G, et al. The newly described mecA homologue, mecALGA251, is present in methicillin-resistant

Staphylococcus aureus isolates from a diverse range of host species. J Antimicrob Chemother. 2012;67(12):2809-13. http:// dx.doi.org/10.1093/jac/dks329 PMID:22941897

4. Shopsin B, Gomez M, Montgomery SO, Smith DH, Waddington $M$, Dodge DE, et al. Evaluation of protein A gene polymorphic region DNA sequencing for typing of Staphylococcus aureus strains. J Clin Microbiol. 1999;37(11):3556-63. PMID:10523551

5. European Committee on Antimicrobial Susceptibility Testing (EUCAST). Breakpoint tables for interpretation of MICs and zone diameters Version 5.0, valid from 2015-01-01. Växjö: EUCAST. Accessed 16 Jun 2015. Available from: http:// www.eucast.org/fileadmin/src/media/PDFs/EUCAST_files/ Breakpoint_tables/v_5.0_Breakpoint_Table_01.pdf

6. Quail MA, Kozarewa I, Smith F, Scally A, Stephens PJ, Durbin $R$, et al. A large genome center's improvements to the Illumina sequencing system. Nat Methods. 2008;5(12):1005-10. http:// dx.doi.org/10.1038/nmeth.1270 PMID:19034268

7. Zerbino DR. Using the Velvet de novo assembler for shortread sequencing technologies. Curr Protoc Bioinformatics. 2010; Chapter 11:Unit 115.

8. Abbott JC, Aanensen DM, Rutherford K, Butcher S, Spratt BG. WebACT--an online companion for the Artemis Comparison Tool. Bioinformatics. 2005;21(18):3665-6. http://dx.doi. org/10.1093/bioinformatics/bti601 PMID:16076890

9. Zankari E, Hasman H, Cosentino S, Vestergaard M, Rasmussen $\mathrm{S}$, Lund $\mathrm{O}$, et al. Identification of acquired antimicrobial resistance genes. J Antimicrob Chemother. 2012;67(11):2640-4. http://dx.doi.org/10.1093/jac/dks261 PMID:22782487

10. Camacho C, Coulouris G, Avagyan V, Ma N, Papadopoulos J, Bealer K, et al. BLAST+: architecture and applications. BMC Bioinformatics. 2009;10(1):421. http://dx.doi.org/10.1186/14712105-10-421 PMID:20003500

11. Cavaco LM, Hasman H, Stegger M, Andersen PS, Skov R, Fluit $A C$, et al. Cloning and occurrence of $c z r C$, a gene conferring 
cadmium and zinc resistance in methicillin-resistant Staphylococcus aureus CC 398 isolates. Antimicrob Agents Chemother. 2010;54(9):3605-8. http://dx.doi.org/10.1128/ AAC.00058-10 PMID:20585119

12. van Wamel WJ, Rooijakkers SH, Ruyken M, van Kessel KP, van Strijp JA. The innate immune modulators staphylococcal complement inhibitor and chemotaxis inhibitory protein of Staphylococcus aureus are located on beta-hemolysinconverting bacteriophages. J Bacteriol. 2006;188(4):13105. http://dx.doi.org/10.1128/JB.188.4.1310-1315.2006 PMID:16452413

13. Viana D, Blanco J, Tormo-Más MA, Selva L, Guinane CM, Baselga R, et al. Adaptation of Staphylococcus aureus to ruminant and equine hosts involves SaPI-carried variants of von Willebrand factor-binding protein. Mol Microbiol. 2010;77(6):1583-94. http://dx.doi.org/10.1111/j.13652958.2010.07312.x PMID:20860091

14. Stegger M, Liu CM, Larsen J, Soldanova K, Aziz M, ContenteCuomo T, et al. Rapid differentiation between livestockassociated and livestock-independent Staphylococcus aureus CC398 clades. PLoS One. 2013;8(11):e79645. http://dx.doi. org/10.1371/journal.pone.0079645 PMID:24244535

15. Loeffler A, Kearns AM, Ellington MJ, Smith LJ, Unt VE, Lindsay JA, et al. First isolation of MRSA ST398 from UK animals: a new challenge for infection control teams? J Hosp Infect. 2009;72(3):269-71. http://dx.doi.org/10.1016/j. jhin.2009.04.002 PMID:19481297

16. GOV.UK. Livestock-associated MRSA found at a farm in East Anglia. London: GOV.UK. 26 Nov 2013. Available from: https://www.gov.uk/government/news/ livestock-associated-mrsa-found-at-a-farm-in-east-anglia

17. Hartley H, Watson C, Nugent P, Beggs N, Dickson E, Kearns A. Confirmation of LA-MRSA in pigs in the UK. Vet Rec. 2014;175(3):74-5. http://dx.doi.org/10.1136/vr.g4620 PMID:25034684

18. Hall S, Kearns A, Eckford S. Livestock-associated MRSA detected in pigs in Great Britain. Vet Rec. 2015;176(6):151-2. http://dx.doi.org/10.1136/vr.h627 PMID:25655544

19. Van Cleef BA, Broens EM, Voss A, Huijsdens XW, Züchner $\mathrm{L}$, Van Benthem BH, et al. High prevalence of nasal MRSA carriage in slaughterhouse workers in contact with live pigs in The Netherlands. Epidemiol Infect. 2010;138(5):756-63. http:// dx.doi.org/10.1017/So950268810000245 PMID:20141647

20. Huber H, Koller S, Giezendanner N, Stephan R, Zweifel C. Prevalence and characteristics of meticillin-resistant Staphylococcus aureus in humans in contact with farm animals, in livestock, and in food of animal origin, Switzerland, 2009. Euro Surveill. 2010;15(16). PMID:20430001

21. Garcia-Graells C, Antoine J, Larsen J, Catry B, Skov R, Denis 0 . Livestock veterinarians at high risk of acquiring methicillin-resistant Staphylococcus aureus ST398. Epidemiol Infect. 2012;140(3):383-9. http://dx.doi.org/10.1017/ So950268811002263 PMID:22082716

22. van Cleef BA, Verkade EJ, Wulf MW, Buiting AG, Voss A Huijsdens XW, et al. Prevalence of livestock-associated MRSA in communities with high pig-densities in The Netherlands. PLoS One. 2010;5(2):e9385. http://dx.doi.org/10.1371/journal. pone.0009385 PMID:20195538

23. Krziwanek K, Metz-Gercek S, Mittermayer H. MethicillinResistant Staphylococcus aureus ST398 from human patients, upper Austria. Emerg Infect Dis. 2009;15(5):766-9. http:// dx.doi.org/10.3201/eid1505.080326 PMID:19402964

24. Pan A, Battisti A, Zoncada A, Bernieri F, Boldini M, Franco A, et al. Community-acquired methicillin-resistant Staphylococcus aureus ST398 infection, Italy. Emerg Infect Dis. 2009;15(5):8457. http://dx.doi.org/10.3201/eid1505.081417 PMID:19402995

25. Witte W, Strommenger B, Stanek C, Cuny C. Methicillinresistant Staphylococcus aureus ST398 in humans and animals, Central Europe. Emerg Infect Dis. 2007;13(2):255-8 http://dx.doi.org/10.3201/eid1302.060924 PMID:17479888

26. Denis O, Suetens C, Hallin M, Catry B, Ramboer I, Dispas M, et al. Methicillin-resistant Staphylococcus aureus ST398 in swine farm personnel, Belgium. Emerg Infect Dis. 2009;15(7):1098101. http://dx.doi.org/10.3201/eid1507.080652 PMID:19624929

27. Aspiroz C, Lozano C, Vindel A, Lasarte JJ, Zarazaga M, Torres C. Skin lesion caused by ST398 and ST1 MRSA, Spain. Emerg Infect Dis. 2010;16(1):157-9. http://dx.doi.org/10.3201/ eid1601.090694 PMID:20031071

28. Cuny C, Layer F, Witte W. Staphylococcus aureus and MRSA in thawing liquid of broiler chicken carcasses and their relation to clonal lineages from humans. Int J Med Microbiol. 2011;301(S1):117. 